\title{
PENINGKATAN HASIL BELAJAR MATEMATIKA SISWA KELAS II SD MELALUI MODEL PEMBELAJARAN KOOPERATIF TIPE STUDENT TEAM ACHIEVEMENT DIVISION
}

\author{
Muslina \\ SDN 133 Pekanbaru, Jl. Ikhlas II No.17, Tengkerang Tim, Pekanbaru, Riau 28131 \\ Email penulis pertama: muslinasdn133@gmail.com
}

\begin{abstract}
One of the efforts of professional teachers to respond the problem of low student mathematics learning outcomes is to apply a model / strategy that can improve mathematics learning outcomes. So this study aims to examine and find out how the learning process uses the STAD type Cooperative model and improve the learning outcomes of mathematics on multiplication material. This type of research is Classroom Action Research (CAR) with data analysis techniques using qualitative and quantitative descriptive approaches. The subjects of this study were elementary school students of grade 2 SDN 133 Pekanbaru. The results of this study that there was an increase in learning outcomes starting from the pre-action stage to the second cycle with a classical increase in the second cycle was $78.79 \%$ which was completed in the mathematics test.
\end{abstract}

Keywords: Cooperative type STAD, Mathematics Learning Outcomes

\begin{abstract}
Abstrak
Salah satu upaya guru profesional untuk menyikapi permasalahan rendahnya hasil belajar matematika siswa adalah menerapkan sebuah model/strategi yang dapat meningkatkan hasil belajar matematika. Maka penelitian ini bertujuan menelaah dan mengetahui bagaimana proses pembelajaran dengan menggunakan model Kooperatif tipe STAD dan meningkatkan hasil belajar matematika pada materi perkalian. Jenis Penelitian yang dilakukan adalah Penelitian Tindakan Kelas (PTK) dengan teknik analisis data menggunakan pendekatan kualitatif dan deskriptif kuantitatif. Subjek penelitian ini siswa SD kelas 2 SDN 133 Pekanbaru Hasil dari penelitian ini bahwa terjadi peningkatan hasil belajar mulai dari tahap pra tindakan sampai ke siklus 2 dengan peningkatan secara klasikal pada siklus kedua adalah $78.79 \%$ yang tuntas dalam tes matematika.
\end{abstract}

Kata Kunci: Kooperatif tipe STAD, Hasil Belajar Matematika

Pelajaran matematika mempunyai peranan yang sangat penting di dalam pendidikan. Seiring dengan perkembangan ilmu pengetahuan dan teknologi, peran matematika sebagai salah satu ilmu dasar yang memiliki nilai esensial yang dapat diterapkan dalam berbagai bidang kehidupan menjadi sangatlah penting. Pola pikir matematika selalu menjadi andalan dalam pengembangan ilmu pengetahuan.

Tujuan pembelajaran matematika meliputi kognitif, afektif, dan psikomotor. Domain kognitif adalah tujuan pendidikan yang berhubungan dengan kemampuan intelektual atau kemampuan berfikir. Domain afektif belajar matematika di sekolah adalah sikap kritis, cermat, obyektif, dan terbuka, menghargai keindahan matematika, serta rasa ingin tahu dan senang belajar matematika. Sedangkan Domain psikomotorik adalah tujuan yang berhubungan dengan kemampuan keterampilan atau skill seseorang. Oleh karena itu, matematika sebagai disiplin ilmu yang mencakup ketiga tujuan pembelajaran tersebut, perlu dikuasai dan dipahami dengan baik oleh segenap lapisan masyarakat terutama siswa sekolah formal. Semua tujuan pembelajaran tersebut bisa dikatakan hasil belajar.

Hasil Belajar itu sendiri menurut Sudjana (2010: 22) bermakna kemampuan yang dikuasai dan dimiliki siswa setelah memperoleh atau menerima pengalaman belajar. Dengan kata lain hasil belajar matematika menurut peneliti adalah kemampuan yang akan dimiliki siswa setelah mengikuti 
materi matematika. Sesuai dengan tujuan pembelajaran matematika, hasil belajar matematika yang akan sangat bermanfaat untuk siswa dalam mengembangkan potensi dirinya baik dari segi kognitif, afektif, maupun psikomotorik.

Faktanya yang temukan oleh peneliti berdasarkan pengamatan yang dilakukan selama ini, proses pembelajaran yang dilakukan masih belum maksimal untuk meningkatkan hasil belajar siswa, karena siswa lebih banyak menunggu penjelasan dari guru saja, tidak ada proses timbal balik antara siswa dan guru. Selain itu, siswa tidak ada berinteraksi berkelompok untuk saling membantu memahami persoalan matematika yang diberikan guru. Fakta lainya, hasil ulangan yang diberikan guru menunjukkan masih banyaknya siswa yang nilai ulangannya masih dibawah KKM. KKM yang ditetapkan sekolah adalah 70. Lalu peneliti mencoba menilik gejala-gejala apa saja yang mempengaruhi masih rendahnya hasil belajar matematika siswa di SDN 133 Pekanbaru, sehingga ditemukan beberapa gejala: (1)Sebagian besar siswa masih belum paham atas materi yang diberikan guru (2)Sebagian besar siswa masih banyak yang tidak memperhatikan guru menerangkan (3)Sebagian besar siswa mengalami kesulitan dalam menyelesaikan soal-soal jika tidak sama dengan contoh dari guru

Ketidakberhasilan suatu proses belajar matematika menurut Sanjaya(2008: 15) bukan hanya disebabkan karena matematika yang sulit, melainkan disebabkan oleh beberapa faktor yang meliputi siswa itu sendiri, guru, metode/media pembelajaran, maupun lingkungan belajar yang saling berhubungan satu sama lainya. Salah satu yang menjadi faktor yang mempengaruhi peningkatan hasil belajar siswa dalah metode pembelajaran yang menarik dan memacu keakifan siswa dalam proses pembelajaran. Maka oleh sebab itu perlu di carikan sebuah solusi metode pembelajaran yang membuat siswa aktif dan saling membagi satu sama lainnya yaitu model Kooperatif Tipe STAD.

Student Teams Achievement Division (STAD) menurut Slavin (2005:143) merupakan model pembelajaran yang mudah dan sederhana serta paling tepat diterapkan oleh pendidik yang baru mulai mengenal pendekatan pembelajaran kooperatif. Sintak dari STAD ini menurut Slavin (2005:11-12) siswa kan belajar secara tim terdiri dari 4 orang yang berbeda-beda baik tingkat kemampuannya maupun jenis kelaminnya, guru menyampaikan infomasi, lalu siswa bekerja secara tim, selanjutnya guru membimbing siswa dalam tim-timnya saat mengerjakan tugas mereka, lalu guru mengevaluasi pekerjaan mereka dengan cara mereka mempresentasika hasil kerjanya, terakhir guru memberikan penghargaan bagi tim yang terbaik.

STAD ini cocok diterapkan untuk meningkatkan hasil belajar matematika siswa. Beberapa penelitian tentang model STAD yang dapat berpengaruh positif terhadap peningkatan nilai hasil belajar siswa, di antara menurut Sunilawati dkk (2013) dalam penelitiannya deengan hasil bahwa dengan menggunakan tipe STAD hasil belajar siswa lebih baik dari pada yang menggunakan pembelajaran biasa. Selain itu penelitian yang juga dilakukan alfiliasni dkk (2014) mengungkapkan bahwa penerapan kooperati tipe STAD berbantuan blok ajabar dapat meningkatkan hasil belajar matematika dalam materi penjumlahan dan pengurangan bentuk aljabar.

Sejalan dengan itu, metode STAD juga sesuai dengan psikologis anak usia sekolah dasar. Hal ini yang di ungkapkan oleh pakar Eggen \& Kauchcak (2004) bahwa prisip-prinsip pembelajaran anak usia sekolah dasar itu harus lah dengan pembelajaran learning the activity of obtaining knowledge (pengetahuan diperoleh dengan aktivitas), interaksi sosial merupakan hal esensial pada perkembangan pembelajaran mereka, dan perkembangan tergantung bahasa. Hal ini berarti sangat cocok sekali dengan metode STAD yang menginginka siswa terlibat aktif dalam proses pembelajaran, adanya interaksi sosial berupa kerja tim, dan penguatan berupa penghargan dengan bahasa pujian sehingga memancing motivasi dan semangat belajar siswa yang mengakibatkan hasil belajar juga meningkat.

Berdasarkan permasalahan yang telah dikemukankan, maka peneliti akan melakukan penelitian dengan tujuan mengetahui (1)proses penerapan STAD pada pokok bahasan perkalian. (2) 
Peningkatan hasil belajar matematika siswa setelah menerapkan strategi pembelajaran Kooperatif tipe STAD.

\section{METODE}

Jenis penelitian yang digunakan peneliti adalah Penelitian Tindakan Kelas (PTK). Menurut Arikunto(2006:96) PTK merupakan penelitian yang diterapkan guru kelas tempat dia mengajar dengan penekanan pada penyempurnaan atau peningkatan proses dab praktis pembelajaran. Penelitian ini menggunakan pendekatan kualitatif dan deskriptif kuatitatif. Pendekatan kualitatif dalam penelitian ini saat mengamati proses proses pembelajaran dengan menggunakan metode STAD, sedangkan statistif deskriptif kuantitatif digunakan untuk data berupa mean, standar deviasi, nilai maksimum, nilai minimum dan diagram-diagram yang digunakan. Penelitian ini menggunakan model Kemmis dan Mc.Tagart yaitu model skema yang menggunakan prosedur yaitu siklus spiral yang terdiri dari perencanaan, tindakan, obsevasi, dan refleksi. Penelitian ini sudah dilaksanakan dalam 2 siklus, dengan masing-masing siklus ada 2 kali pertemuan, serta d akhir setiap siklus di adakan tes untuk mengukur peningkatan hasil belajar siswa. Tidakan pendahuan peneliti dalam penelitian ini adalah dengan memberikan tes kepada sisw dan menganalisis secara klasikal hasil tes tadi.

Subjek peneltian ini adalah seluruh siswa kelas 2 SDN 133 Pekanbaru yang berjumlah 33 orang siswa. Siswa laki-laki berjumlah 14 dan siswa perempuan 19, dengan pokok bahasan perkalian bilangan.

Analisis ketuntasan hasil belajar siswa setelah menerapkan kooperatif tipe STAD dapat dilakukan dengan membagi jumlah siswa yang tuntas belajar dengan jumlah siswa secara keseluruhan. Kriteria ketuntsan siswa kelas II SDN 133 Pekanbaru dapat dikatakan meningkat jika: (1) Ketuntusan perorgan, seorang siswa dikatakan tuntas jika menapaik nilai $\geq 75$ dari dinilai ideal 100. (2)ketuntasan secara klasikal, suatu kelas dikatakan tuntas jika terdapat minimal $75 \%$ yang memperoleh nilai $\geq 75$ dari maksimal $100 \%$.

\section{HASIL DAN PEMBAHASAN}

Analisis data deskriptif kuantitatif data penelitian mulai dari pra tindakan, siklus 1, dan siklus 2 disajikan dalam tabel 1.1 berikut:

Tabel 1.1 Data Hasil Belajar Siswa Secara Klasikal

\begin{tabular}{lllll}
\hline No & $\begin{array}{l}\text { Hasil Belajar yang } \\
\text { Tuntas }\end{array}$ & Pra tindakan & Siklus 1 & Siklus 2 \\
\hline $\mathbf{1}$ & $\begin{array}{l}\text { Ketuntasan } \geq 75 \text { dari } \\
\text { nilai maksimal t100 }\end{array}$ & $60.60 \%$ & $72.73 \%$ & 78,79 \\
$\mathbf{2}$ & $\begin{array}{l}\text { Tidak memenuhi } \\
\text { KKM }(<75)\end{array}$ & $27.40 \%$ & $21.21 \%$ \\
Total & $100 \%$ & $100 \%$ & $100 \%$ \\
\hline
\end{tabular}

Berikut ditampilkan pula dalam bentuk diagram batang peningkatan hasil belajar matematika siswa pada pra tindakan, siklus 1 dan siklus ke 2 ketika sudah diterapkan model STAD yang terlihat pada gambar 1.1: 


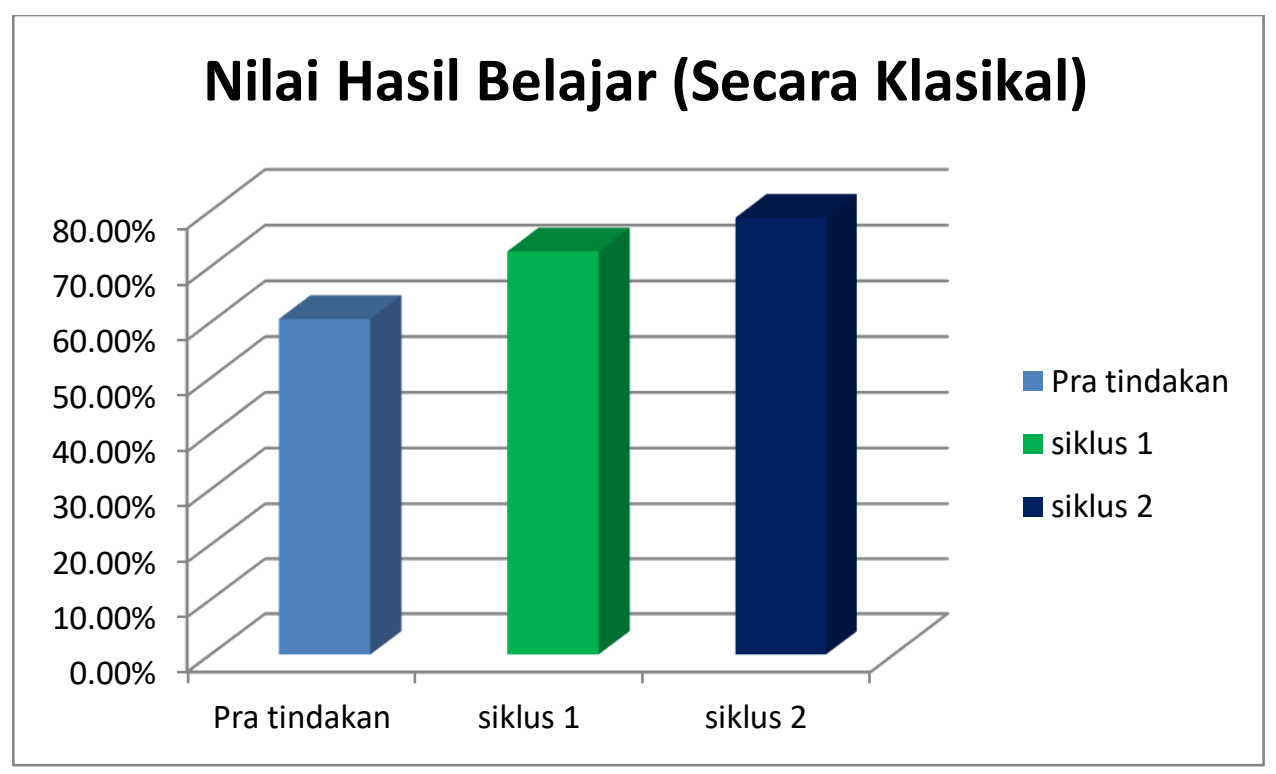

Gambar 1.1. Diagram Batang Peningkatan Hasil Belajar Siswa

Dari tabel 1.1 dan gambar 1.1 terlihat bahwa ketuntasan siswa secara klasikal mulai dari pra tindakan sampai ke siklus ke 2 mengalami peningkatan. Hasil belajar siswa yang tergolong dalam kategori tuntas pada tes pendahuan hanya sekitar $66,67 \%$ yaitu sebanyak 20 orang siswa. Pada siklus pertama pada tabel 1.1 terlihat sudah ada peningkatan secara klasikal yang tuntas $\geq 75$ sekitar $72.73 \%$ yaitu 24 orang siswa. Pada siklus ke-2 juga terus meningkat sehinggPa tercapai ketuntasan hasil belajar secara klasikal sesuai dari kriteria ketuntusan yaitu sekitar $78.79 \%$ yaitu 26 orang siswa yang tuntas dari 33 orang siswa.Hal tersebut berarti penelitian tindakan kelas nya telah selesai pada siklus 2 .

\section{Pembahasan Pra tindakan, Siklus 1, dan Siklus 2}

Pembelajaran pra tindakan ini dilaksanakan sebanyak satu kali pertemuan ( 2 x 45 menit) pada pokok bahasan perkalian. Pelaksanaan pembelajaran dilakukan dengan menerapkan pembelajaran semua penyajian disampaikan oleg guru disertai penugasan. Selanjutkan ketika mulai menerapkan Model Kooperatif tipe STAD, peneliti ternyata membutuhkan 2 siklus untuk meningkatkan hasil belajar siswa.

Pada siklus pertama, peneliti atau guru melakukan mulai tahap perencanaan sampai tahap refleksi. Pada siklus 1 ini secara klasikal ketuntasan hasil belajar sudah sampai $72.73 \%$ yaitu 24 orang siswa, namun belum memenuhi standar yang telah ditetapkan sebelumnya. Maka oleh sebab itu guru melakukan reflesi hasil dari observasi yang telah dilakukan oleh observer. Dari hasil pengamatan, bisa dilihat keaktifan siswa sudah mulai tampak dalam mengikuti pembelajaran. Hal ini dapat dilihat dari keseriusan siswa berdiskusi dalam menyelesaikan masalah yang ada pada Materi yang diberikan guru. Peran guru membimbing siswa juga sangat memberi respon yang baik bagi siswa. Sebagian siswa sudah mulai terbiasa dalam melaksanakan proses pembelajaran kooperatif dengan Pendekatan Investigasi Kelompok tersebut, namun masih ada juga siswa yang main-main dalam diskusi, berjalanjalan ke kelompok lain untuk melihat hasil kelompok lain sehingga mereka ini juga dapat mengganggu ketenangan dalam kerja kelompok lain. Untuk itu peneliti sebagai guru akan melakukan 
Peningkatan Hasil Belajar Matematika Siswa Kelas II SD Melalui Model Pembelajaran Kooperatif Tipe Student Team Achievement Division, Muslina

perbaikan yaitu pada pertemuan selanjutnya guru akan lebih menfokuskan pada kelompok yang belum pernah tampil ke depan untuk mempresentasikan laporannya, sehingga mereka benar-benar mengerjakan materi yang diberikan guru. Dan pada kegiatan akhir, guru mempersingkat waktu untuk menyimpulkan dan lebih menambahkan waktu untuk mengerjakan soal quiz.

Pada siklus kedua, peneliti sudah memperbaiki berdasarkan hasil refleksi pada siklus pertama. Siswa sudah mulai terbiasa dalam kelompok, dan mulai aktif bekerja dalam kelompok, hal ini dapat terlihat pada gambar 1.2 berikut ini:

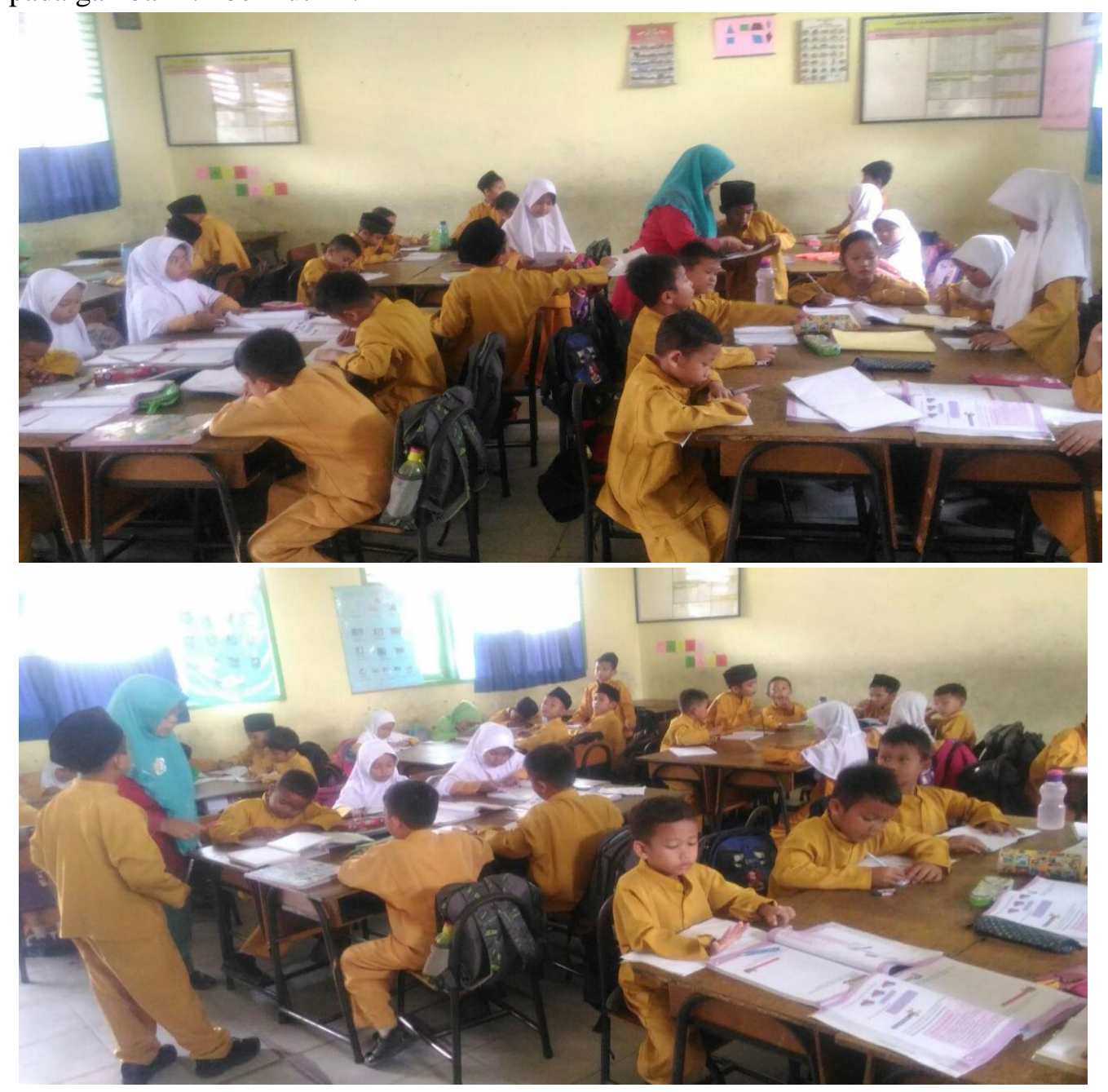




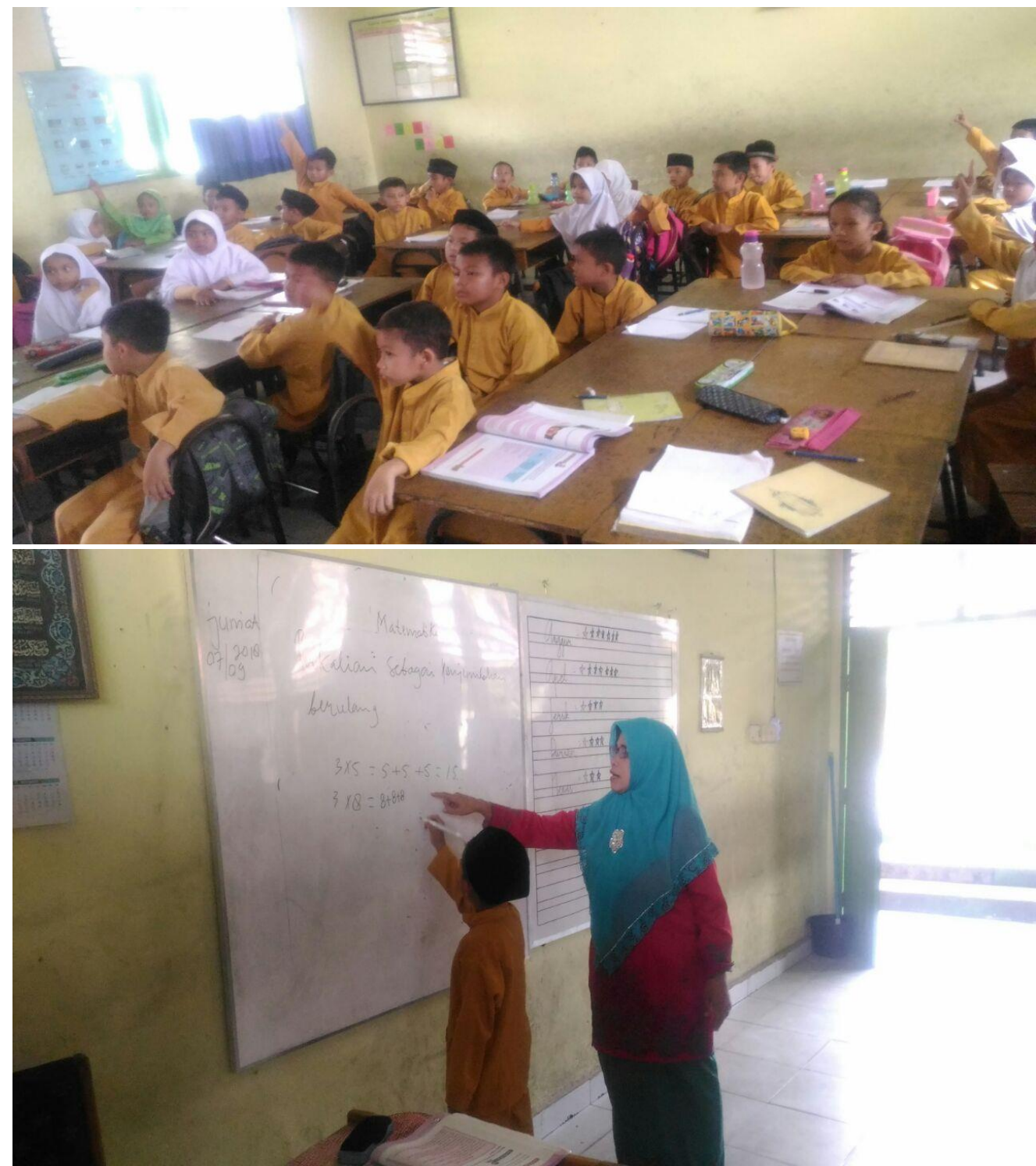

Gambar 1.2. Proses Pembelajaran model Kooperatif tipe STAD

Pada gambar 1.2 terlihat bahwa Keaktifan siswa dalam belajar sudah memuaskan, ditandai dengan adanya kesungguhan siswa dalam proses pembelajaran. siswa sudah bisa berdiskusi dengan baik dalam menyelesaikan masalah dan tidak hanya meniru pekerjaan temannya. Selain itu siswa berani mempresentasikan hasil kerjaan yang mereka kerjakan, dan siswa/kelompok lain mau bertanya apabila ada yang tidak mereka mengerti.Dari data tes hasil belajar yang diadakan pada siklus 2 terjadi peningkatan dari sebelumnya.

Proses penerapan pembelajaran Kooperatif tipe STAD setiap pertemuan nya dengan materi perkalian sangat tepat digunakan karena siswa berusaha memahami dan mempelajari tentunya dengan arahan dan bimbingan guru sebagai fasilitator, dan saling berbagi pengetahuan sesama tim kelompok mereka. Hal ini sesuai yang dikatakan oleh Eggen \& Kauchcak (2004) bahawa siswa akan belajar dengan aktivitas yang mereka lakukan dan itu akan bertahan lama diingatan mereka serta mereka akan senang beriteraksi sosial antar mereka hal tersebut dapat dilihat pada gambar 1.2. Selain 
Peningkatan Hasil Belajar Matematika Siswa Kelas II SD Melalui Model Pembelajaran Kooperatif Tipe Student Team Achievement Division, Muslina

meningkatkan aktivitas mereka Proses pembelajaran Kooperatif tipe STAD dapat juga meningkatkan Hasil belajar siswa, hal tersebut dibuktikan dengan peningkatan hasil belajar siswa siklus yang dapat dilihat pada gambar 1.1.

\section{KESIMPULAN}

Berdasarkan hasil dari siklus 1 dan siklus 2 yang telah dilakukan peneliti, maka dapat diambil kesimpulan: (1) Proses pembelajaran menggunakan model kooperatif tipe STAD yang dilakukan guru adalah sebagai berikut: menyampaikan apersepsi berupa memotivasi siswa dalam belajar, menggorganisasikan kelompok diskusi untuk kerja tim yang telah diatur sebelumnya, menyajikan materi dan memberi informasi penting, membimbing siswa dalam menyelesaikan materi yang diberikan guru, memberikan tugas, dan memberikan penghargaan berupa pujian dan lain sebagianya untuk memotivasi siswa yang tampil terbaik.(2) dengan menerapkan model pembelajaran Kooperatif tipe STAD hasil belajar siswa terus meningkatkan, dan pada siklus kedua sudah mencapai target yang di inginkan guru secara klasikal yaitu sekitar $78.79 \%$ siswa sudah mencapai nilai $\geq 75$.

\section{DAFTAR PUSTAKA}

Alfiliansi dkk. (2014). Penerapan Model Pembelajaran Kooperatif Tipe Stad Berbantuan Blok Aljabar Untuk Meningkatkan Hasil Belajar Siswa Pada Penjumlahan Dan Pengurangan Bentuk Aljabar Di Kelas Viii Smp Negeri 12 Palu. Jurnal Eletktronik Matematika Tadulako, vol.02 no.02,hal 133.

Arikunto,S. (2006). Prosedur Penelitian Suatu Pendekatan Praktek.Jakarta: Rineka Cipta Eggen,P., Kauchack,D.( 2004). Educational Psychology.New Jersey: Merril Prentice Hall Slavin, Robert E, (2005). Cooperative Learning Teori Riset dan Praktik, Bandung: PT Nusa Media

Sudjana,Nana.(2010). Penilaian Hasil Proses Belajar Mengajar.Cet XV. Bandung:Remaja Rosdakarya

Sunilawati, ni made dkk (2013).Pengaruh Model Pembelajaran Kooperatif Tipe Stad Terhadap Hasil Belajar Matematika Ditinjau Dari Kemampuan Numerik Siswa Kelas IV SD. E-Journal Program Pascasarja Universitas Pendidikan Ganesha Jurusan Pendidikan Dasar vol.3, hal.7 